\title{
MALRAUX'S QUEST: FRATERNITY AND EVIL IN THE WALNUT TREES OF ALTENBURG
}

Nicolas de Warren*

\begin{abstract}
This article explores the depiction of war and fraternity in André Malraux's The Walnut Trees of Altenburg. Special emphasis is placed on examining Malraux's literary presentation of the first use of gas warfare in the First World War and the emergence of a genuine hope of fraternity amidst the apocalypse of absolute war. Through a detailed analysis of Malraux's haunting description of the fictionalised battle of Bolimov, key themes in Malraux's life-long struggle with the confrontation between fraternity and evil are discussed in depth against a broader evocation of the destructiveness of the First World War.
\end{abstract}

'L'immense vent de l'avenir souffle la paix. Que faire contre l'ouragan de fraternité et de joie?'

-Victor Hugo

I

This war would be a war like no other. On 25 August I9I4, three weeks after German troops invaded Belgium on the 4th August, and just shy of two months since the fateful assassination of the Archduke Franz Ferdinand and his wife in Sarajevo on 28th June, German soldiers sacked the city of Leuven and destroyed its celebrated university library. Some three hundred thousand books and over a thousand irreplaceable manuscripts were burnt in addition to the torching of two thousand buildings and the killing of 248 civilians. The destruction of Leuven was so intense that Dietrich Mahnke, who studied with Edmund Husserl, and who was serving in the 75th Reserve Infantry Battalion, could still observe the city burning on 27th August as his company marched

*KU Leuven, Institute of Philosophy, Husserl-Archive, Kardinaal Mercierplein 2, 3000 Leuven. Email: nicolas.dewarren@hiw.kuleuven.be

Literature \& Theology (C) The Author 2015. Published by Oxford University Press 2015; all rights reserved. For Permissions, please email: journals.permissions@oup.com 
through the village of Korbeek-Lo towards Herent a few kilometers Northwest of Leuven. ${ }^{1}$

Two weeks after the sacking of Leuven, the Cathedral at Reims, one of the great architectural achievements of Medieval Europe, was severely damaged by German shellfire. By mid-September I9I4, the expectations on both sides, Allied and German, for a decisive victory before Christmas had cruelly evaporated. As the Germans began to establish entrenched positions a few kilometers from Reims in view of its ruined cathedral, the iconic image of the First World War-trenches, mud, frontal assaults, military deadlock-began to settle across the Western Front. George Bataille, seventeen years old and serving in the I54th infantry regiment, meditated on the cathedral's desecration in his first publication Notre-Dame de Reims. As he reflected: 'I thought that corpses themselves did not mirror death more than did a shattered church as vastly in its magnificence as Notre-Dame de Rheims.'2

Outrage at the destruction of the University of Leuven Library and Reims Cathedral was among intellectuals and the broader public immediate and swift. In one of his numerous missives against the war, Romain Rolland penned an open letter to the German writer Gerhard Hauptmann on 29 August I9I4, condemning this 'assault on culture and humanity'. Henri Bergson, President of l'Académie des Sciences Morales et Politiques, in a short declaration published in the Bulletin des Armées de la Republique (4 November I9I4), loudly decried the 'barbarism reinforced by the capture of civilization'. In the words of British Prime Minister Asquith in a letter written at the end of August, 'the burning of Louvain is the worst thing [the Germans] have yet done. It reminds one of the Thirty Years' War'. As Sir Arthur Evans, famed archaeologist who excavated Knossos, declared in an open letter published in The Times, 'Sir, may I be allowed to voice horror and profound indignation at the Prussian holocaust of Louvain.'3

Outrage resonated on both sides of the front line that took shape not only across the fields and forests of France and Flanders, but as significantly across the entire cultural and intellectual landscape of Europe. In response to this outcry against 'German Barbarianism', German intellectuals and university professors in turn became incensed. A vocal defence of the Leuven Library's destruction was published a week later, as well as an appeal by three hundred German university professors, Au monde civilisé, An die Kulturwelt, on 4 October I9I4. At the height of the war in I9I7, in an open letter to Americans, published by his fellow German Hugo Munsterberg, professor at Harvard, Husserl would write about the pervading sense of 'national isolation' in its 'sacred war'. As he writes: 'They [soldiers, including his two sons, one of whom, Wolfgang, died at Verdun in I9I6] have gone out to fight this war in the Fichtean spirit as a truly sacred war, and to offer themselves as a sacrifice to 
the fatherland; and now they are pilloried before the world as atrocious barbarians.'

The destruction of these two spiritual monuments of Western civilisation crystallised a perception of the war as absolute in a metaphysical and existential sense. Whereas the Library symbolises the universality of humanitas through the ideal of a Republic of Letters, the Cathedral symbolises the universality of deus through the ideal communion between City of Man and the City of God. When thus symbolically understood, the destruction of Leuven Library and Reims Cathedral can be seen as heralding the double-death of Man and God - in the eyes of André Malraux, the two projects of 'anti-destiny'-the attempt to surpass human transience- that defined European Civilisation until its twentieth-century catastrophe. As the American writer Henry James, residing in England, grasped lucidly in I9I5 in a letter to Howard Sturgis:

The plunge of civilization into this abyss of blood and darkness by the wanton feat of two infamous autocrats is a thing that so gives away the whole long age during which we have supposed the world to be, with whatever abatement, gradually bettering, that to have to take it all now for what the treacherous years were all the while really making for and meaning is too tragic for any words.

II

In the afternoon of 22 April I9I5, along a six-kilometre front on the Ypres Salient, a greenish-yellow cloud hovered over the ground, slowly creeping towards the trench lines of unsuspecting French soldiers, pushed by a gentle wind. As Willi Siebert, serving in the newly formed 'gas pioneer' battalion, and who had studied chemistry as well as pharmacy before the war, recalled:

The wind kept moving the gas towards the French lines. We heard cows bawling, and the horses screaming. The French kept on shooting... Then everything was quiet again... In a while it had cleared and we walked past the empty gas bottles. What we saw was total death. Nothing was alive. All of the animals had come out of their holes to die. Dead rabbits, moles, and rats and mice were everywhere. The smell of gas was still in the air. It hung on the few bushes which were left. When we got to the French lines the trenches were empty but in half a mile the bodies of French soldiers were everywhere. It was unbelievable... You could see where men had clawed at their faces, and throats, trying to get breath. Some had shot themselves. The horses, still in the stables, cows, chickens, everything, all were dead. Everything, even the insects were dead. ${ }^{4}$

Under the direction of the Faustian chemist Fritz Haber, whose wife, Clara Immerwahr, took her own life on the very evening of her husband's 'success' 
at Ypres, the German Army released one hundred and fifty tons of chlorine gas from cylinders quietly placed along the front line. Although the German forces did not fully exploit (nor anticipate) the lethality of this first application on the Western Front of gas warfare, a modest gain of territory was achieved. The Kaiser was proud. This use of gas was not the first, nor the last. A few months earlier, at the battle of Bolimov (3 I January I9I5) on the Eastern Front, the Germans fired eighteen thousand artillery shells filled with tear gas against Russian positions, with little military effect. At Bolimov and Ypres history witnessed the first employment of (modern) chemical agents of war. Both events announced the dawn of an ever-accelerating conspiracy between human ingenuity and inhuman destructiveness that would define and haunt the legacy of the twentieth century. Of the four basic states of matter (solid, liquid, gas, and plasma), only the state of gas had since the origins of human warfare remained unweaponised; with the First World War, all forms of elemental nature had now succumbed to the human artistry of war. This military development of gas warfare marks the twentieth century's attainment of an historically unprecedented ontological power of destruction, where human beings not only employed their intelligence and industry to destroy each other, but where humanity achieved an unholy potency of destruction comparable to, if not surpassing, nature as well as divinity. Everything-even the insects - were dead.

Of the many grim inventions produced during the First World War, poison gas, although limited in its military effectiveness vis-à-vis other weapons and eventually withheld from use in subsequent European conflicts (stockpiled by the Allies and the Axis powers during the Second World War, yet never used), possessed a unique symbolic, indeed, mythical, power of significance. In Wilfred Owen's iconic poem Dulce et Decorum Est, the haunting description of comrades in the death throes of a gas attack-'As under a green sea, I saw him drowning' — culminates with an indignant indictment of 'the old Lie; Dulce et Decorum est / Pro patria mori'. In John Singer Sargent's painting Gassed, a procession of blinded soldiers are led to a dressing station amidst dead and wounded littered on the ground, bathed in the yellowish glow of a sunset tainted by the lingering wash of mustard gas. In his etching Stormtroopers Advance Under Cover of Gas, Otto Dix depicts five soldiers in gas masks and battle gear, charging head-on in contorted poses, appearing against a desolate landscape as inhuman wraiths.

It is arguably André Malraux who most fully exploited the mythical suggestiveness and historical significance of the deployment of gas in the First World War, to the point of fashioning a philosophical allegory for the entire sweep of the twentieth century. The portrait of a gas attack on the Eastern Front in his I943 wartime novel The Walnut Trees of Altenburg re-imagines the first actual use of gas at Bolimov in a quasi-mythical light, representing 
nothing less that 'the reappearance of Satan in the world'. Decades after he first wrote this description of a gas attack in The Walnut Trees of Altenburg, Malraux would return to this episode from his own novel; or better, this episode would continue to haunt him until it resurfaced in his literary imagination with convulsive force as he faced the imminent possibility of his own death in a Parisian hospital in 1972 (he would die in I976). Suspended between life and death in a condition of paralysis in his hospital bed, Malraux begins to write what he senses to be his last book, Lazarus, with the observation: 'I have returned to an event which I described in The Walnut Trees of Altenburg thirty years ago, one of those unforeseeable and shattering events, which, like the Children's Crusade... seem like History's bouts of madness: the first German gas attack, at Bolgako on the Vistula in I9I6. ${ }^{5}$ The date (I9I6), the name (Bolgako), as well as the depiction of the gas attack in The Walnut Trees of Altenburg, are fictional, and yet proximate enough to an actual event it implicitly evokes (I9I5, Bolimov) so as to render such a fictionalisation of an historical event the only substantial means by which historical truth can be revealed. ${ }^{6}$

In the hour of death - the death of man whose life uniquely crisscrossed the twentieth century as writer, adventurer, politician, and intellectual, whose individual destiny intersected with the lives of Picasso, Gide, Mao, Nehru, and de Gaulle, whose biography was inseparable and at times confounded with the course of the twentieth century so to have become one of its principal witnesses and moral conscience-Malraux confronts his own mortality by confronting the mortality of humanity in the twentieth century. As he reflects, 'That attack on the Russian front has been succeeded by Verdun, the mustard gas of Flanders, Hitler and the extermination camps." 7 Even as Malraux admits that 'he does not know why the Vistula attack' exercises such a profound fascination on his imagination, this spectral presence of truthful fiction-his self-fashioned 'Myth of the Vistula'-returns to him in the hour of his dying as very the quest of Malraux's own existence, and in that singular endeavour to be Malraux, as the very the quest of the twentieth century. As he recognises, 'and if I return to this [the gas attack at Bolgako], it is because I am seeking the crucial region of the soul where absolute Evil is pitted against fraternity'.

The description of the gas attack at Bolgakov inserted into Lazarus, and with which this final installment of his antimemoires La Corde et les Souris begins, is taken verbatim from Malraux's earlier novel The Walnut Trees of Altenburg. This novel is itself a fragment of a larger novel, La lutte avec l'ange, the manuscript of which was destroyed by the Gestapo with Malraux's arrest in I944. ${ }^{8}$ In its thus 
fragmentary status, The Walnut Trees of Altenburg is the last novel written by Malraux - 'a curious fragment detached from a hypothetical book to come'. Much as with Adorno's interpretation of Beethoven's last piano sonata Op. I I I, Malraux's final, albeit incomplete, novel takes leave of the genre of the novel. The strangeness of the novel's form and content jarred many of its first readers, including André Gide, who found especially annoying Malraux's use of abstract terms within its dramatic narrative. ${ }^{10}$ Gide's annoyance reflected one of the numerous ways in which Malraux flaunted his eschewing of novelistic conventions, especially the unity of action, time and place, as well as any internal consistency in the style of writing. Whereas the second part of the novel stages a philosophical discussion among characters in the library of Altenburg, the third part contains a philosophical allegory of the gas attack at Bolgakov. With each shift in the novel's narrative, both the form and the content of the novel becomes subjected to an internal transformation that reflects the internal transformations of the novel's principal character, Vincent Berger, the father of the first-person narrator with which the novel begins and ends.

The novel opens and ends with the first-hand account of the narrator's captivity in a German prisoner of war camp in I940 France. ${ }^{11}$ The narrator, a French soldier from Alsace, finds himself in the ruins of the Chartres Cathedral amidst wounded comrades: 'I cannot make out the shape of the cathedral; the panes that have replaced the stained glass in the nave rip it open with sunshine' - a sunshine sharply juxtaposed with 'the tidal roar of German tanks streaming past [the cathedral]'. ${ }^{12}$ Awaiting transportation in the ruins of the Chartres Cathedral, the narrator and his comrades are invited to fill out preprinted Red Cross postcards informing their families of their condition: wounded, well treated, etc. Once settled behind the barbwire fences of a POW camp, sheets of paper are blown by the wind into the camp from the town of Chartres - the very postcards the French POWs had earlier written. Immersed in a flood of abject humanity, the narrator comes to confront directly the question of humanity. As he reflects: 'As a writer, by what have I been obsessed for the last ten years, if not by mankind? Here I am face to face with our basic essence.' 13 This seizure by the question of 'mankind' triggers in turn the memory of his own father, who, as a soldier twenty-five years earlier, had fought in the First World War, not, however, against the Germans, but as a German officer (Alsace belonged at the time to Germany) against the Russians. His father's memoirs remain unpublished, and are in fact no more than a mass of notes in which he reflected and recorded 'his encounters with mankind'-encounters that, much as the postcards blown back to the narrator in his situation in POW camp in I940, are recollected in the novel, blown back, as it were, into the memory of the narrator, as its three main sections. 
The subsequent three main sections of the novel follow the adventures of the narrator's father, Vincent Berger, who, as an Alsatian, served in the German Army during the First World War. These three sections form a triptych: in the first panel, Berger serves as an advisor to the Young Turk Enver Pasha prior to the outbreak of the First World War. In the second panel, Berger returns from Constantinople to his native town of Altenburg to the news of his father's suicide and participates in a philosophical discussion at the library at Altenburg on the question 'does humanity have a foundation?'. In the third panel, with the outbreak of the war in I9I4, Berger is sent to the Eastern Front and witnesses the first use of gas at the battle of Bolgakov. Throughout each of the panels, Berger's attitude towards human existence and the world becomes transformed, and with each stage in Berger's Bildungsroman, his identity is placed under the star of a particular philosophical constellation. Unlike a classic Bildungsroman, Berger's transformation from adventurer to thinker to historical witness does not culminate in the achievement of self-possession or self-knowledge. Instead, the narrative ends with Berger losing consciousness (himself affected by the gas) as he is carried to a field hospital: 'He could make out the sun gleaming on the metalwork of a gas mask, and next to him the gesticulations of a Russian officer. ${ }^{14}$

The Walnut Trees of Altenburg is composed through transitions in time and space across discontinuous topoi. The narrative spans the Second and First World Wars, thus linking both conflicts into a thirty-years conflagration connected across the filial generations of grandfather, father, and son. The transitions between the opening setting of the narrator in 1940 and his father's adventures in the First World War orchestrates a shift in alignment of fronts, or front-line experience: the Alsatian (father) in the First World War serves in the German Army against the Russians; in the Second World War, the Alsatian (son) serves in the French Army against the Germans. This reorientation reflects in a condensed form the entire problematic of Europe through the prism of the generational and geo-political ambiguity of the ontological identity of Alsace.

Despite the juxtaposition of discontinuous topoi within a narrative structure that does not culminate with any final denouement (in fact, the novel ends where it begins: in the limbo of a POW camp in I940 France), The Walnut Trees of Altenburg is unified by the pervasive question of the human condition - 'the fundamental enigma of man'. In his antimemories, Malraux declared: 'Que l'Homme devienne l'objet d'une recherche et non d'une révélation... Mais l'homme n'atteint pas le fond de l'homme; il ne trouve pas son image dans l'étendue des connaissances qu'il acquiert, il trouve une image de lui-même dans les questions qu'il pose. L'homme que l'on trouvera ici c'est celui qui s'accorde aux questions que la mort pose à la signification du monde. ${ }^{15}$ The question of human existence is pursued in Malraux's novel 
through the development of different forms of questioning along three shifting axes: in the form of heroic adventure, or a life of action on the historical stage; in the form of contemplation, or theoretical reflection; in the form of a witness to history who cannot remain detached, and who loses consciousness in the truth revealed as an Apocalypse of Hope.

In the first panel, Vincent Berger is cut from the cloth of T.E. Lawrence in his role as attaché to Enver Pasha. ${ }^{16}$ Cast in the form of a heroic life, Berger seeks to fathom 'the fundamental enigma of man' in the form of a personal adventure to insert himself into history. In its metaphysical meaning, the heroic form of life is the attempt of an individual to emancipate herself from one's contingent identity and dependence on origins (cultural, psychological, etc.). Much as with the historical personage of T.E. Lawrence, the heroic existence seeks to overcome his identity through self-creation and transformation that is as much internal as it is external. As an external transformation, Berger leaves Europe for the Near East, and thus moves from the 'centre' to the 'periphery', from 'Europe' to the 'Orient'. This geopolitical trajectory traces a movement into History as Berger seeks to change history through his role as advisor to the revolutionary Enver Pasha. In Malraux's conception, the abandonment of Europe represents an abandonment of European individualism. Rather than find the truth of humanity within the interiority of the self, Berger's quest after the 'enigma of man' takes the form of a life of action on the stage of history. Berger sheds his identity as a selfinteriorised individual dislocated from History in transforming himself into an historical agent who is more than what he has been, who, in his newly fashioned heroic agency, defines his identity through political and historical engagement. Much as with T.E. Lawrence, the cause that newly defines him is not his own, yet in becoming what is most properly his own, it becomes his singular destiny.

Within the universe of Malraux's imagination, the cause of establishing the 'union of all Turks throughout Asia' taken up by Berger functions as a kind of metaphysical allegory for the sublimation of the individual into the absolute of an historical Absolute. Malraux does not shy away from further ascribing a metaphysical function to Islam as a civilisation defined essentially in relation to God, not humankind, in contrast to secular Europe. And yet, much as with T.E. Lawrence, Berger's Orientalism ultimately leads to profound disillusionment as the historical Absolute to which he is committed increasingly comes to abolish his own individuality. Berger returns to his native town of Altenburg after an adventure on the world-historical stage that took him to the far reaches of Afghanistan. His alienation from his attempt to become a world-historical individual is experienced as a return to earth, and specifically, as a return to his native soil and the rootedness of the immemorial walnut trees of Altenburg. The topos of 'return to earth' is central to Malraux's writings. In 
Le Miroir des Limbes, Malraux speaks of his own experience of 'returning to earth' as having played a significant role in his own life, and which he attempted to communicate in his writings, for example, with the 'hero of Altenburg'. This experience consists in returning to one's own civilisation after having been transfigured through an attachment to another, alien civilisation. As Malraux observes, the 'wonder' and 'awakening' (l'étonnement) of such a return is that 'la mort nous est plus étrangère que l'étranger'. ${ }^{17}$ The 'return to earth' is a Malrucian figuration of memento mori. As Malraux explains: 'la terre suggère la mort par sa torpeur millénaire comme par sa métamorphose'. ${ }^{18}$

Berger's return announces the abandonment of any conception of man based on European individualism but also, any conception of man based on the absorption of the individual in a universal, or absolute. Human existence lacks a foundation in (European) individualism or in the (Oriental) cosmic absolute (whether God or History). ${ }^{19}$ The question 'is there any factor on which we can base the notion of man' that becomes explicitly debated in the library of Altenburg has been answered negatively through the metaphysical consequence of Berger's 'return to earth'. A foundation for man can neither be found in any notion of individualism nor in any form of supra-individual absolute. And yet, the philosophical debate staged at Altenburg concludes inconclusively, thus revealing the limitation of the contemplative attitude towards the enigma of man. Berger's meditations in the wake of the inconclusive debate presents him with an unresolved dilemma: human existence has no significance beyond civilisation and history, and thus 'fundamental man' is nothing other than ever-changing configurations without an enduring essence. 'Fundamental man' is a myth. As one of the interlocutors (Möllberg) expresses this position: 'the everlastingness of man can be conceived, but it's an everlastingness in nothingness'. ${ }^{20}$ Or else, 'fundamental man' can only be found in an archaic or 'pre-historical' nature, in which case, man is also nothingness, i.e. the nothingness of brute animality. Malraux thus ingeniously redefines Pascal's anthropology of human existence as caught between two infinities, but here, in Malraux, it is the nothingness of culture and the nothingness of nature. ${ }^{21}$ While Berger rejects any identification of the 'fundamental' of human existence with divine transcendence or with the universality of history, his fascination with the cosmos-the infinite multiplicity of natural landscapes, the mysterious robustness of the walnut trees-evokes in him the presence of a secret, the meaning of which will only be revealed in the Apocalypse of Hope, which, unsuspectingly, he shall soon witness.

Walking outside the library, Berger admires a pair of walnut trees, the magnificence of which he grasps in their great branches and bursting leaves, as if digging into the earth, in a form of rooting that, as he observes, does 'not sprout from the trunk'. Between this pair of walnut trees, Berger can glimpse 
in the distance the Strasbourg Cathedral 'as so many other trunks framed cathedrals in the meadows of the West'. The Cathedral's tower 'stands erect like a cripple in prayer' in its support of the weight of the world in contrast to the rootedness of the walnut trees 'flourishing with life'. ${ }^{22}$ Berger experiences something akin to a mystical intuition of a primitive élan vital; the secret of 'the fundamental of mankind' is suggested in the inversed image of the walnut tree escaping, or transcending, its own rootedness, or situation, through a flourishing of a vitality that enroots it in the world. Humanity must likewise create from its own nothingness an image of its grandeur.

With the outbreak of the First World War, Berger is thrust once again into history. Called back to service, Berger is assigned to escort Professor Hoffman, who has just arrived on the Eastern front to deploy a new form of warfare: lethal gas. On the eve of the attack, the professor along with his son in tow, Berger and another German officer, Captain Wurtz, are housed in the symbolically named hotel Europa in a local village just behind the front lines. They exchange pleasantries and begin to show each other photos of their families. There is a very matter of fact discussion of the favourable conditions for the up-coming test and Professor Hoffman dashes off a few final calculations. All of these exchanges bear the stamp of normality, and even the brief discussion concerning the rationale for the employment of gas is shaped by an apparent reasonableness: Germany has no other choice; gas will ultimately save us with a quick victory; gas is the most humane weapon. With these discussions, Malraux paints in an impressionistic manner the inclusion of the spirit of evil, materialised in poison gas, into structures of the life-world, as well as the fault lines between a traditional culture of aristocratic officers (Captain Wurtz) and the nascent military-industrial complex of scientist-soldiers (Professor Hoffman) in view of this novel weapon of Biblical destruction.

The next morning, the entourage arrives at the front line to supervise the final deployment of the gas canisters and the release of their deadly contents. While waiting for the attack to begin, Berger overhears from his command trench the banter of soldiers in a forward trench, whom he cannot directly see, as they wait for the order to attack. These bits and pieces of conversation snatched by the observant Berger offer an image of the life-world of the common soldier in contrast to the genteel fraternity of the officers in hotel Europa. Berger overhears talk concerning family life, the perception of the enemy, wartime rumours, the showing of photos, and daily life in an army at war. At a remove and invisible from the front trench of attacking soldiers, Berger occupies the contemplative position of the spectator. In the darkness of this observation trench, he hears voices detached from faces and occasionally 
glimpses the fleeting outline of a soldier's movements. The talk he hears is the talk of soldiers in common fraternity with each other in anticipation of death. As he remarks: 'I'm listening perhaps to those who are about to die', but perhaps a more incisive formulation would be here Geoff Dyer's haunting expression with reference to the poetry of Wilfred Owen: 'those who are going to have died. ${ }^{, 23}$ As the narrator comments: 'The shafts of daylight dimmed: a flight of migrant birds was sweeping across the sky toward the Vistula. Through the thick penumbra Berger listened to the voice of the only species that knows-however dimly- that it can die. ${ }^{24}$

The experience of foreboding in the anticipation of death became a common trope of First World War poetry, literature, and philosophical reflection. In Heidegger's analysis, authentic anticipation towards death allows not only for an individual to adopt a stance of resolution towards his own finite existence, but, as significantly, allows for the forging of a community of those who are about to face death resolutely. In Malraux's novel, however, the sense of foreboding witnessed by Berger manifests itself in the idle chatter and gossip, which Heidegger deemed the inauthentic talk of the they (das Man)' in contrast to the authentic call of conscience of our own individual finitude. In Berger's experience, the front-line experience is stripped bare of any heroic self-sacrifice, duty, or authenticity. As the narrator recounts: 'Listening in this live darkness, my father was conscious for the first time of the people of Germany. Or perhaps just of people: men. A voice close to the darkness of primitive man, like these silhouettes barely visible in the shadows. ${ }^{25}$ What Berger apprehends is the depth of a fraternity more fundamental than national identity and cultural signification (indeed: we could imagine the same types of conversation among Russian soldiers). The individual voices form something akin to a Greek chorus that resembles increasingly the voices of silence. There is of course talk against the enemy and the bravado of 'when we get over there, eh, to Petersburg, to Paris', so this palaver is not fully disarmed of talk against an enemy, the Russians. And yet, this chorus of fraternity minted in the currency of idle chatter opens a window of fraternity, which, however, immediately becomes closed with the order to attack. As the soldiers receive the command 'Gas masks on' and 'over the top', as Berger observes, 'they appeared in profile, the snouts of their gas masks jutting out in front of them'. Emerging from their trenches, they are no longer men, but strange creatures from an alien, hostile world advancing as inhuman wraiths.

The opening barrage has ceased. Silence descends upon the forest and the valley below: 'The radiance of this valley was inseparable from the distant song of larks, the sound of crickets, living noises; and to these was due the silence that covered everything like the clear pale sky, rather than to the last echo of shell-bursts, which was the war. ${ }^{26}$ Freely employing his imaginative license, 
Malraux has set the battle in the Biatowiem Forest, the legendary primal forest straddling modern Poland and Belarus. Although strictly speaking historically inaccurate, this resetting of the battle of Bolgako in the Biatowied Forest (heavily damaged during the First World War by the Germans as an exploitable natural resource) sets the gas attack within a mythical dimension. Malraux thus creates not only a 'historization' of fiction or 'fictionalization' of history; more ambitiously, this feat of Malrucian imagination fashions a mythical fiction meant to reveal the truth of an historical event. This displacement of the historical battle to a fictional site is nonetheless anchored in an actual historical place that is itself full of historically imagined significance. As Simon Schama explores in Landscape and Memory, the Biatowien Forest has historically always been an imaginary forest, as a pristine Urwald and 'zoological utopia', by generations of claimants: Poles, Lithuanians, Russians, Germans. ${ }^{27}$ In Adam Mickiewicz's epic poem Pan Tadeusz, the Biatowiez Forest is celebrated as the primitive paradise of a mystically infused Eden. In Malraux's imaginary space, however, the sedimentation of imaginary significance has become displaced. The displacement is double: not only the displacement of the historical battle to the fictional site of the Biatowiea Forest but reciprocally, Malraux's fictional juxtaposition displaces the Forest from its various historically accrued symbolic meanings. Malraux's displacement of the Forest from its history, its fictionalisation, as it were, as the site for the (historical) battle of Bolgako, neutralises such historical symbolisations, and in so doing, as Malraux repeats the basic form of imagining the Forest as an Urwald as yet untouched by humanity and yet, at the same time, the 'secret cradle-world' for humanity.

This Malrucian repetition of the original fabulation of the Biat owieg Forest evokes the last remaining tract of great primeval forest in Europe-a Europe now divided into geographical regions of cultivation and civilisation. As the site for an historical battle that was in fact not fought there, the Forest is fictionalised into the last edge of Europe, the end of Europe, where the end of European man will play itself out, and where Satan will reappear onto the stage of European history and enter the twentieth century.

And then the gas is released: a dense, creeping cloud spreads out across the landscape and engulfs entirely the forest and the valley. Nothing stirs as everything, including nature itself, waits in apprehension. Silence. And then: 'a neigh came across the valley, carried from a long way off on the wind'. Bursting from the direction of the Russian trenches, a riderless horse emerges from the blanketed landscape, dashing left and right, stopping and galloping. The horse appeared like a 'dog howling'. No sooner had this crazed animal broken the stillness and anticipation, it darts back into the thick blanket of gas, no longer to be seen, yet leaving behind its piercing neigh that 'began to give this commonplace fog the look of a war machine'. 
This image of a demented horse might very have been suggested to Malraux by Picasso's Guernica, which Malraux has seen in Picasso's studio in Paris. As with Picasso's devastating evocation, animals and humans are caught up in the savage brutality of war. A human cry merges indiscernibly into the cry of an animal. Borrowing a notion from Gilles Deleuze, the brutality of war opens a zone of indiscernibility between man and animal. The cry of the riderless horse and the cries of soldiers merge together to reveal a primordial suffering beyond any distinction between man (culture) and animal (nature). For what Deleuze calls 'meat' (viande) is distinct from the human body understood as a lived-body (le chair). In the suffering of meat (viande): 'the man who suffers is a beast, the beast that suffers is a man'. ${ }^{28}$ In Malraux's text, a comparable distinction is drawn between the suffering of meat and the pain of (human) lived-body. The depth of suffering manifest in war, and especially with the advent of gas warfare, reveals an evil against a more fundamental sense of existence than captured through the distinction between culture and nature. The violation is cosmic against life as such, and hence the destructiveness of the gas spares nothing living. It is indiscriminate in its lethality towards the living while allowing the inorganic-rocks, buildings, etc.- to remain unscathed. In contrast to other weapons, gas single-mindedly targets all that is living-life as such.

The Russian lines remain however without sign of life as the Germans decide to advance. As the Germans penetrate into the gas cloud and approach Russian trenches, they encounter no resistance or response: no defensive artillery barrage, no chatter of machine guns, no firing. From his command trench, Berger observes the advancing troops as 'puppets', 'spiders', and 'insects', yet quickly loses visual contact. And then he begins to witness a confusing scene. ${ }^{29}$ German soldiers, one by one, or in small groups, are beginning to trickle back towards their own trenches. Berger decides to investigate and heads towards the retreating German soldiers. As he penetrates into the shrouded woods, he discovers a scene of utter desolation: blackened trees, dead grass, leaves dead, a dead horse in a convulsed position. As he observes: 'Apple trees pruned by man, killed like men: more dead than the other trees, because fruitful. Beneath them, all the grass was black. Black, too, and slimy, the trees enclosing the horizon... dead the earth. ${ }^{30}$ Everything, even the insects, are dead. The pollution is total: the earth is contaminated and shall no longer breed the living.

The devastation wrought on the primeval Biat owiea Forest is compared to a Biblical Scourge and the undoing of creation. The cloud of gas that drowns landscape and memory in evil is the Flood unleashed by the hand of man. 'Satan,' as Malraux comments in Lazarus, 'reappears on earth' as the 'spirit of evil' stronger than death. As the gas moves through the forest, we witness the unholy undoing of creation, as if the order of divine creation had been 
revoked and the earth returned to the welter and waste before divine creation. The welter and waste that God had separated in order to create the vault of heaven and the home of earth creeps back over creation and suffocates all of creation. Although poison gas is a human invention, it brings into world the otherworldly material presence of the spirit of Evil. The gas is the materiality of this inhuman spirit. And thus, even as a human invention, gas materialises in the world a spirit of destructiveness that is irreducible to the human. Through the application of human technology, mankind has acquired a destructive power greater than destructivity proper to nature, and which had always separated nature from culture. In this manner, as argued in a comparable manner by W.G. Sebald in Luftkrieg und Literatur with reference to the aerial bombing campaigns of the Second World War, the ontological difference between history and nature collapses. ${ }^{31}$ What form of human life remains possible in the aftermath of the Apocalypse? It cannot be a life that either seeks to imitate nature or to define itself in contrast to nature. Resurrection would only be possible through a humanity discovered on the other side of the distinction between nature and culture.

\section{V}

Berger comes across a first batch of confused, gassed, and retreating German soldiers: 'Plastered with leaves, the soldiers he met in their flight all looked at him with the same wild expression of hate, as though he had been responsible for an ambush, and they refused to answer him. ${ }^{32}$ The collapse of the distinction between nature and culture is here reflected in the grotesque, halfanimal, half-human, apparitions that emerge from the chaos of the battlefield. His own men appear to him as creatures from another planet and look upon him as an enemy. Berger has entered a zone of indiscernibility where the difference between friend and enemy, man and nature, has collapsed entirely. In the disorder of battle, order, hierarchy, and forms of recognition have been effaced, and Berger finds himself in a primitive situation in which men are reduced to bare survival in the landscape of devastated nature.

Berger suddenly comes across another frightful apparition of two soldiers, one carrying the other, the wounded soldier's arms hanging as in a 'Descent from the Cross'. At first, he believes that the soldiers are German, that a German is carrying his wounded comrade back to safety. Upon closer inspection, however, the wounded soldier is in fact Russian. The German 'had the face of an old, old peasant'. In the narrator's description: 'The Russian's lips and eyes showed purple in his grey skin. His nails were scratching at his shirt, trying to tear it apart, without being able to get hold of it. ${ }^{33}$ The symbolic recognition of the wounded soldier as a Christ-like figure appears through the misrecognition of the wounded as German, thus neutralising the implied 
contrast between friend and enemy that framed the expectation that a German soldier would be carrying one of his comrades - and not an enemy - to safety. The German soldier's face is covered by a gas mask, and the entire appearance of the masked German soldier carrying a dying Russian soldier gives the impression of a single, strange creature, as if the two bodies had merged into something grotesque that nonetheless delineates a 'clumsy, heartrending brotherhood'. As this misshapen creature approaches Berger, he distinguishes the Russian from the German, and the German lifts his gas mask-face revealed-and his look is that of hatred in contrast to the 'hideous gas-infected face' of the Russian on his shoulders. The apparition of Christ is displaced from any Christian context and becomes fully humanised to the extent that the human has itself become 'bestial'.

Berger comes upon an even more horrific scene as he advances further:

In the middle of it a man was leaping on all fours, with such spasmodic jerks that it seemed he was being bounced along. Naked. Two yards off, the apparition lifted its grey face and whiteless eyes, opened its epileptic mouth as though to scream; my father drew back. Mad with pain, moving like any madman, as though its body was now only possessed by torment, with a few frog-like leaps it plunged into the putrescence. ${ }^{34}$

This apparition enacts a dislocation between the visual and auditory: much as with the screaming head in Francis Bacon's series of paintings, perceptively discussed by Gilles Deleuze, the open mouth expresses such a depth of suffering as to render any scream, indeed, any expression, impossible. The silence is itself the scream. And suddenly it becomes perforated by a scream that appears from nowhere: in 'prehistoric silence, there was a scream, a scream of utter agony which ended up in a mew'. Berger gazes around him to witness 'dead piles, more or less naked, clutching at each other in convulsive groups'. Convulsed by this spectacle of horror, Berger becomes transformed in the revelation of a primitive fraternity in the throes of evil: "The Spirit of Evil was stronger here than death, so strong that he felt compelled to find a Russian, any Russian who had not been killed, put him on his shoulder and save him., ${ }^{, 35}$

In this Apocalypse Hope, the front-line experience becomes decentred from the axis of a confrontation between friend and enemy. Beginning with the apparition of the riderless horse until Berger's transformation from his contemplative position of witness to fraternal engagement, the front-line experience has shifted to the only genuine opposition in war: not the front between German and Russian, but the front between fraternity and absolute evil. The turning back on the advancing German troops, the gas, at first directed against the Russians, turns the front back against itself. The veritable confrontation in any war is not the existential decision of who is the enemy 
but the revelation that the fraternity hangs in the balance against the spirit of evil. Unleashed by the actions and intentions of humans, the spirit of evil transcends humanity in producing the false front between friend and enemy. The only genuine enemy of mankind is evil. As Jean-François Lyotard formulates this central Malrucian insight: 'Sous les affrontements historiques, une autre guerre, la vraie, est depuis toujours engagée. Est-ce une guerre? Elle confond les adversaires: elle les mêles, et elle les abuse. Elle se joue du manichéisme.'36

The Promethean Revolt realised in Berger's engagement in the saving of Russian lives represents Berger's discovery of the 'fundamental man' and the truth of human existence as a struggle of fraternity against absolute evil. ${ }^{37}$ This redemptive movement towards the enemy who becomes denuded of any traits of civilisation in his abjection does not stem from any natural sympathy for the suffering of others or other comparable natural disposition, much as with Rousseau, towards others. Berger himself reflects on the source of this spontaneous charity:

Was it pity? He vaguely wondered, as he had wondered when he had seen the companies [of German soldiers] retreating; it was something a good deal deeper, an urge in which pain and brotherhood were inseparably united, an urge that came from far back in the past... as far as the dazzling blue sky, the hillside sloped upwards with its rediscovered smell of trees, the smell of box-wood and fir trees rustling under a shower of rain. ${ }^{38}$

This immemorial fraternity merges with an affirmation of life that becomes absorbed and reflected in the sensuous vitality of nature. The primitive fraternity here at issue is thus both inhuman and human; it marks a peculiar form of anti-humanism that seeks to resurrect a genuine humanism that has broken with the opposition between culture and nature, friend and enemy. ${ }^{39}$ Even the term 'fraternity' does not adequately name what is proper-the proper name- of humanity that at the end of the twentieth century still awaits us. As Malraux reflects in Lazarus:

Why is it [fraternity] the faithful companion of death? I feel the need of it today... Fraternity is rarely absent from these images, and the scenes on the Vistula haunted me because of it. People think they understand fraternity because they confuse it with human warmth; it fact, it is a sentiment that comes from the depths... Like the sacred, it eludes us if we strip it of its primitive, irrational element... Let us guard against giving it its trivialized name. ${ }^{40}$

\section{REFERENCES}

1 Mahnke's war diaries are available online: ${ }^{2}$ For the English translation, see D. http://sdvigpress.hypotheses.org/cat egory/mahnke-tagebuch. Hollier, Against Architecture: The Writings of George Bataille, trans. B. Wing 
(Cambridge, MA: MIT Press, I989), pp. I 5 -I9.

3 Quoted in: A. Kramer, Dynamic of Destruction: Culture and Mass Killing in the First World War (Oxford: Oxford University Press, 2007), p. I4.

4 Quoted in: D. Dendooven, '22 April I9I5-Eyewitness accounts of the first gas attack', in 1915, Innocence Slaughtered? The First Gas Attack, or the Transformation of Society in Total War, ed. J.P. Zanders, Unpublished papers of the 2005 In Flanders Fields Museum Conference. My gratitude to Pieter Trogh for making these papers available to me.

5 A. Malraux, Lazarus, trans. T. Kilmartin (New York: Grove Press, 1978), p. 6.

6 On the notion of 'fictional truth', see M. Riffaterre, Fictional Truth (Baltimore, MD: John Hopkins University Press, I990). Malraux based his recreation on the account of the battle provided by a German intelligence officer, Max Wild, the full text of which can be found in Oeuvres Complètes, Vol. II. On the complex relation between history and fiction in Malraux's novel, see P. Tame, 'History and Fiction in Les noyers d'Altenburg', in André Malraux: Across Boundaries, ed. G. Harris (Amsterdam: Rodopi, 2000).

7 Malraux, Lazarus, p. 4.

8 For details of Malraux's capture, see O. Todd, Malraux: A Life, trans. J. West (New York: Alfred A. Knopf, 2005), ch. 22.

9 P. Sabot, Littérature et guerres: Sartre, Malraux, Simon (Paris: PUF, 2010), p. 93.

10 A. Gide, Journal (Paris: Gallimard, I997), p. 992.

11 For a detailed analysis of the novel, see Sabot, Littérature et guerres.

12 The Walnut Trees of Altenburg, trans. A.W. Fielding (Chicago, IL: University of Chicago, I992), p. II.

13 Ibid., p. 24.

14 Ibid., p. I86.

15 A. Malraux, Oeuvres Complètes (Paris: Gallimard, I996) Vol. III, p. I2.
${ }^{16}$ On the importance of T.E. Lawrence for Malraux's novel, see V. Carchidi, 'Rebels Against Absurdity: André Malraux, T.E. Lawrence, and Political Action', in Literature and War, ed. D. Bevan (Amsterdam: Rodopi, I989).

17 Malraux, Vol. III, p. 73.

18 Ibid., p. 6.

19 On this point, see R. Girard, 'L'Homme et le Cosmos dans l'Espoir et dans Les Noyers de l'Altenburg', in Publications of the Modern Language Association of America, LXVIII (1953) 49-55.

20 Walnut Trees of Altenburg, p. I Iо.

21 For an exposition of the importance of Pascal for Malraux, see Sabot, op. cit.

22 On Malraux's use of the walnut tree as a pivot against Maurice Barrès' discussion of the anecdote 'l'arbre de M. Taine' in his I897 novel Déracinés, see Sabot, Littérature et guerres, pp. I59-60.

23 G. Dyer, The Missing of the Somme (London: Vintage, 1994).

24 Walnut Trees of Altenburg, p. 22. As Malraux further reflects about his narrative (and alter-ego) of Berger: 'It is not he who interests me: it is the voice from the depths overheard in the trench, howling or stifled by the silence of the forest' (Lazarus, p. 54).

25 Walnut Trees of Altenburg, p. I43.

26 Ibid., p. I 53.

27 S. Schama, Landscape and Memory (London: Vintage, I995), pp. 23-75.

28 G. Deleuze, Francis Bacon. The Logic of Sensation, trans. T. Conley (Minneapolis, MN: University of Minnesota Press, 2003), p. 20.

29 At the actual battle, the tear gas blew back towards the German lines and failed vaporise due to freezing temperatures.

30 Walnut Trees of Altenburg, p. I35.

31 See W.G. Sebald, On the Natural History of Destruction, trans. A. Bell (New York: Modern Library, 2004).

32 Walnut Trees of Altenburg, p. I68.

33 Ibid.

34 Ibid., p. 175. 
35 Ibid., p. 176.

36 J.-F. Lyotard, Chambre sourde (Paris: Galilée, I998), p. 8I.

37 As Malraux comments himself in Lazarus: 'The sudden revulsion of the soldiers of the Vistula revealed in each one of them the counterpart of the man whom he was meant to fight and whom he was saving.'

38 Walnut Trees of Altenburg, p. I84.

39 As Malraux notes in Les voix $d u$ silence, 'L'Humanisme... c'est dire: "Nous avons refusé ce que voulait en nous la bête, et nous voulons retrouver l'homme partout où nous avons trouvé ce qui l'écrase."' On Malraux's humanism within the broader spectrum of twentieth-century French thought, see S. Geroulanos, An Atheism That Is Not Humanist Emerges in French Thought (Stanford, CA: Stanford University Press, 20I0).

40 Malraux, Lazarus, p. I05. 